\title{
STRATEGI PENINGKATAN EKSPOR PRODUK KELAUTAN DAN PERIKANAN KE PASAR EROPA
}

Ali Mursit ${ }^{1}$, Agus Wahyono ${ }^{2,}$ Yuli Setiawan ${ }^{3}$

Universitas Bengkulu ${ }^{1}$, Universitas Satya Negara Indonesia ${ }^{2,3}$

a.muqsit@unib.ac.if, agoeswahyono@usni.ac.id² yulisetiawan05@gmail.com³

\begin{tabular}{lcl}
\hline Received : & Accepted: & Published: \\
1 Januari 2022 & 15 Februari 2022 & 25 Februari \\
2022 & & \\
\hline
\end{tabular}

\begin{abstract}
ABSTRAK
Indonesia sebagai negara kepulauan yang memiliki sumberdaya alam khususnya sumber daya perikanan. Sektor ekspor perikanan Indonesia terus mengalami trend positif dengan terus naik dengan kenaikan 5,72\% dan nilai pada tahun 2020 mencapai USD 5.205 miliar dengan komoditas perikanan jenis udang, tuna-tongkol-cakalang, rumput laut, cumi-sotong-gurita, rajungan-kepiting, dan lainnya. Kegiatan ekspor perikanan ke Uni Eropa ada beberapa hambatan yaitu antara lain ketatnya standar aturan dagang di Uni Eropa, belum adanya kesepakatan dagang bebas Indonesia, produsen yang cenderung sering berganti dan rendahnya kualitas SDM nelayan dan belum sesuai standar mutu hasil perikanan yang dihasilkan. Peningkatan ekspor sektor perikanan dan kelautan ke Uni Eropa diperlukan beberapa strategi antara lain; 1. Pengoptimalan potensi sumber daya laut untuk meningkatkan kegiatan ekspor; 2. Meningkatkan kerjasama baik dengan negara lain maupun dengan lembaga internasional dalam hal-hal yang terkait dengan produksi dan pengawasan mutu produk perikanan; 3. Peningkatan pengelolaan perikanan nasional berbasis WPP; 4. Pemberdayaan dan pengoptimalan hasil tangkapan nelayan kecil dengan menerapkan standar kualitas internasional; 5. Pembinaan tentang penanganan hasil perikanan standar ekspor; 6. Perbaikan infrastruktur, sarana prasarana terutama untuk melaksanakan C3Q (cold chain system dan sanitasi serta hygiene); 7. Pengoptimalan sistem SLIN (Sistem Logistik Ikan Nasional); 8. Peningkatan peranan pemerintah dalam menjaga food safety dan ecolabelling; 9. Mengusung prinsip pengelolaan perikanan berkelanjutan; 10. Membentuk lembaga/ bagian yang khusus mengkoordinasikan pelaksanaan riset keamanan hasil perikanan, risk analysis (risk assessment) hasil perikanan sebagai dasar dalam menentukan tujuan keamanan pangan (food safety objectives); 11. Mensinergikan antara pemerintah sebagai regulator dan pengusaha sebagai eksekutor.
\end{abstract}

Kata kunci : Ekspor, Mutu, Perikanan Berkelanjutan, Sumber Daya Ikan, Strategi

\section{ABSTRACT}

Fishery resources produced amounted to 12.5 million tons/year with an economic value of $\$ 2.04$ billion USD. From 2016 - 2020 Indonesia's fisheries export sector continues to experience a positive trend by continuing rises with an increase of $5.72 \%$ and in 2020 the value was reached of $\$ 5.205$ billion USD. The export sector who dominates is with fishery products have code 0303 , and fishery commodities types shrimp, tuna, skipjack, seaweed, squid-octopus, crabs, etc. There are several obstacles i.e strict on standards of trade rules in the EU, the absence of Indonesia's free trade agreement with the EU, producers that tend to change frequently and the low quality of fishermen's human resources and not yet in accordance with the quality standards of fishery products produced. In increasing exports of Indonesia's fisheries and marine sector, several strategies are needed, i.e;1) 
Optimization of the potential of fish resources to increase export activities; 2) Enhance cooperation with other countries and with international institutions related to the production and quality supervision of fishery products; 3) Improved WPP-based national fisheries management; 4) Empowerment and optimization of catches of small fishermen by applying international quality standards; 5) Coaching on handling export standard fishery products; 6) Improvement of infrastructure, facilities, especially to carry out C3Q. 7) Optimization of SLIN system; 8) Increased role of government in maintaining food safety and ecolabelling; 9) Promote the principle of sustainable fisheries management; 10) Establish a special institution to coordinate the implementation of fishery product safety research and risk analysis of fishery products as a basis in determining food safety goals; 11) Synergize between government as a regulator and employers as a executor.

Keywords: Export, Fish resources, Quality, Strategy, Sustainable fisheries

\section{PENDAHULUAN}

Indonesia salah satu negara yang memiliki tingkat keanekaragaman jenis sumber daya baik hayati maupun hewani yang tinggi. Indonesia memiliki berbagai bentuk produk perikanan yang sudah diolah menjadi produk unggulan dan kemudian diekspor ke berbagai negara. Salah satu sumber daya Indonesia adalah ikan, cumi lobster dan udang. Menurut Kementrian Perdagangan (2014), Komoditas ekspor produk perikanan Indonesia meliputi udang, tuna, kerapu, kakap, tenggiri, tilapia, cephalopoda (squid, ocopus, cuttlefish), daging kepiting ranjungan, kepiting, rumput laut, teripang, lobster. Sumber daya tersebut perlu diolah lebih baik sehingga dapat meningkatkan pendapatan Indonesia.

Indonesia menjadi negara produsen pengekspor produk ikan hidup, produk segar maupun olahan ke berbagai Negara. Menurut Kementrian Perdagangan (2014) terdapat 10 komoditas ekspor antara lain produk segar, produk hidup, produk beku, produk kaleng, produk kering, produk asin kering, produk asap, produk ferementasi, produk masak dan Surimi based product. Salah satu produk yang banyak di ekspor ke Eropa selain ikan adalah udang. Selain itu yang diekspor ke Eropa adalah Tuna. Fachrudin (2003) menyatakan bahwa dalam kegiatan ekspor produk kelautan masih didominasi oleh beberapa produk konvensional untuk konsumsi antara lain seperti udang dan ikan.

Berdasarkan Kementerian Perdagangan (2021) sektor ikan dan udang sejak tahun 2016-2021 mengalami tren peningkatan sebesar $3.73 \%$ dimana sejalan dengan hal tersebut, berdasarkan Kementerian Kelautan dan Perikanan Dirjen penguatan daya saing preikanan dan kelautan (2021) menyatakan bahwa ekspor hasil perikanan Indonesia pada tahun 2020 mencapai \$5,205 Miliar USD, dan nilai ekspor hasil perikanan mengalami tren positif dengan kenaikan sebesar $5,72 \%$ per tahun dalam rentang waktu 2016-2020.

Selain itu masih ada permintaan pasar akan ikan beku, ikan beku adalah adalah proses pembekuan ikan dibawah $0^{\circ} \mathrm{C}$. Ikan beku banyak diminta di Slovakia terutama permintaan produk seafood antara lain fish fillets. Berdasarkan data dari kantor Pusat Statistik Slovakia, volume perdagangan Indonesia pada tahun 2021 mencapai $€ 148.978 .104$ (euro) dan pada tahun 2013 mencapaiy $€ 119.663 .621$. berdasarkan hal tersebut menunjukkan bahwa peluang untuk kegiatan ekspor Indonesia ke pasar Slowkia masih cukup terbuka antara lain dalam bentuk produk kelautan (udang, ikan, kerang, dsb) KBRI Bratislava, 2015. Indonesia masih memiliki peluang potensi pasar eropa untuk komoditas perikanan dan kelautan, menurut Kedutaan Indonesia Brussel (2021) dari sisi peluang, saat ini estimasi sektor perikanan dan kelautan yang boleh ditangkap lebih kurang 10 juta ton per tahun dari 12.5 juta potensi perikanan dan kelautan yang ada. Berdasarkan beberapa sumber data diperlihatkan bahwa produksi perikanan tangkap Indonesia, sebagai negara dengan luas perairan yang sangat besar 
masih sangat sedikit dibandingkan dengan beberapa negara lain yang memiliki perairan cenderung lebih sedikit. Selain dari komoditi perikanan tangkap, sector budidaya perikanan di Indonesia juga dinilai cukup meyakinkan mengingat besarnya dukungan potensi lahan perikanan budidaya yang sangat luas yang mencapai 2,8 juta ha lahan budidaya air tawar, 2,96 juta ha lahan budidaya air payau, dan 12,12 juta ha lahan budidaya laut.

Dalam kegiatan ekspor dari Indonesia ke negara lain masih memiliki berbagai permasalahan, BAPPENAS (2005) menyatakan bahwa tantangan yang dihadapi adalah meningkatnya hambatan non tarif awal dengan isu lingkungan seperti ecolabelling, selain itu investasi perdagangan internasional produk perikanan tak hanya dipengaruhi dari permintaan dan penawaran tetapi juga ditentukan oleh konvensi serta perjanjian internasional di sektor perikanan, serta standar aturan yang berbeda yang diberlakukan negara importir pada negara ekspor. Menurut Fachrudin, permasalahan lainnya adalah permodalan dari pihak perbankan Indonesia kepada Pengusaha karena ketidakpastian dan sifat musiman dari bidang kelautan sehingga belum melayani peminjaman kepada Pengusaha, sedangkan masalah lain adalah masalah transportasi pengirimin dari produk perikanan Masalah lainnya seperti masih ada produk Indonesia yang masih terkontaminasi logam, kotoran, cemaran dan bahan tambang yang melebihi ambang batas sehingga produk Indonesia mengalami penolakan

Produk yang akan di ekspor memang perlu dilakukan peningkatan kualitas dari nelayan maupun stakeholder lain, perlu kerjasama berbagai pihak dalam peningkatan kualitas ekspor ikan baik dalam hal penangkapan ikan, pengemasan ikan, transportasi ikan maupun teknologi pengolahannya sehingga semakin meningkat permintaan dari negara lain.

\section{METODE PENELITIAN}

Metode analisis yang digunakan dalam studi ini yaitu berupametode analisis deskriptif. Data yang digunakan dalam penelitian ini terdiri dari data primer dan data sekunder. Analisis data yang digunakan adalah berupa analisis deskriptif dan SWOT, Analisis deskriptif didasari dari telaahan studi pustaka dengan menggunakan data sekunder sebagai sumber informasi, sedangkan Analisis SWOT merupakan identifikasi dari berbagai faktor secara sistematis yang mana bertujuan untuk merumuskan strategi (Rangkuti, 2014).

\section{HASIL DAN PEMBAHASAN}

Indonesia salah satu negara maritime yang memiliki wilayah perairan yang sangat luas dan memiliki kekayaan sumber daya alam laut, bumi yang sangat melimpah (Pursetyo et al., 2015). Tyas dan Ikhsani (2015) menyatakan bahwa Indonesia memiliki potensi sumber daya alam yang bisa menjadi peluang untuk memajukan. Dengan sumberdaya alam tersebut menjadikan Indonesia sebagai negara yang memiliki potensi perikanan yang sangat besar baik dari segi kuantitas maupun diversitasnya (Kusdiantoro et al., 2019. Sektor perikanan merupakan tulang punggung bagi masyarakat pesisir dimana sebagai sumber pendapatan dan ekonomi (Effendi et al., 2019; Yanfika et al., 2020). Yusuf et al. (2017) menyatakan bahwa Indonesia mempunyai peluang sangat besar untuk menjadi salah satu produsen dan eksportir utama produk perikanan ke negara lain. Dalam perencanaan pembangunan kelautan dan perikanan harus didasari dari konsep pengelolaan berkelanjutan yang didukung oleh pengembangan sektor industri berbasis sumber daya alam dan sumber daya manusia agar mempunyai nilai daya saing yang tinggi (Soemarni et al., 2015). Menurut Nurlina (2018) salah satu arah pembangunan sub sektor perikanan ke depan yaitu membangun sub sektor perikanan yang berkeunggulan kompetitif (competitive advantage) berdasarkan keunggulan komparatif (comparative advantage). Putri (2018) menyatakan, walaupun mempunyai potensi perikanan tangkap yang besar, Indonesia saat ini hanya menduduki urutan kedua sebagai negara produsen ikan tuna setelah Thailand 
di kawasan ASEAN, hal ini disebabkan adanya perbedaan tingkat pemanfaatan baik dari segi volume maupun IPTEK penggunaan alat tangkap. Thailand saat ini menjadi negara pengekspor tuna olahan terkuat di dunia dan menguasai pasar dengan pangsa 46,75\% (Lestari et al., 2013). Selain pesaing, terdapat beberapa masalah lain berupa hambatan tarif dan non tarif yang dialami oleh komoditas ikan dan masalah kenaikan harga bahan bakar minyak di Indonesia yang memberikan efek banyak kapal tidak beroperasi ke laut lagi. Faktor lainnya yaitu sifat komoditas perikanan yang selalu aktif berpindah tempat/beruaya sesuai dengan musim dan cuaca sehingga membuat sulit untuk melakukan kestabilan kuantitas dan kualitas dalam kegiatan penangkapan ikan. Adapun faktor lain Lebih dari 90\% nelayan Indonesia adalah nelayan kecil yang menangkap ikan di daerah pesisir. Hal tersebut menjadi peluang yang besar sekaligus tantangan untuk memperkuat usaha perikanan tangkap skala kecil agar lebih maju, mandiri, dan berkelanjutan (KKP, 2020).

Menurut FAO (2018) Indonesia merupakan produsen perikanan tangkap nomor 23 di dunia setelah China. Dari sektor hasil perikanan dan hasil industri perikanan Indonesia menyumbang sebesar 2,6\% dari produk domestik bruto yang dihasilkan Indonesia. Sedangkan sektor budidaya perikanan menyumbang hasil produksi sekitar dua pertiga dari produksi perikanan Indonesia. Berdasarkan statistik ekspor perikanan (2020), Volume hasil perikanan Indonesia dalam periode 2016 s.d. 2020 naik sebesar 4,13\%. Dan kenaikan nilai sebesar 5,72\% dari 2016-2020. Indonesia juga menyumbang sebanyak $7 \%$ produksi ikan tangkap di seluruh dunia.

Hambatan tarif yang diterapkan oleh negara-negara tujuan ekspor khususnya Uni Eropa sangat merugikan bagi negara Indonesia. Dimana hambatan non tarif yang terjadi berhubungan dengan beberapa hal seperti : perizinan ekspor, sertifikasi kesehatan, standar sanitasi, standar mutu, isu lingkungan, isu hak asasi manusia, dan terorisme (Purnomo, 2015). Daya saing ekspor menjadi salah satu faktor penting dalam perdagangan internasional, negara yang memiliki daya saing yang rendah hanya akan menjadi pasar sasaran produk dan jasa dari negara-negara lain pesaingnya. Yohan (2006) menyatakan bahwa kondisi daya saing menjadi salah satu kriteria dalam penentuan keberhasilan suatu negara di dalam persaingan pasar dagang internasional. Produk olahan perikanan Indonesia agar dapat bertahan dalam pasar internasional khususnya di pasar Uni Eropa perlu mengetahui faktor-faktor apa saja yang mempengaruhi daya saing ekspor produk olahan perikanan.

Besarnya sumberdaya ikan yang ada di perairan Indonesia menjadikannya Indonesia memiliki salah satu komoditi ekspor yang sangat dapat diandalkan dalam meningkatkan devisa negara. Adapun komoditas ekspor produk perikanan Indonesia saat ini meliputi udang, tuna, kerapu, kakap, tenggiri, tilapia, cephalopoda (squid, ocopus, cuttlefish), daging kepiting ranjungan, kepiting, rumput laut, teripang, lobster. Komoditas perikanan tersebut kemudian diolah menjadi produk perikanan berupa produk akhir. Jenis proses penanganan serta pengolahan produk ikan terdiri dari produk hidup, produk segar (fresh product) melalui proses pendinginan, produk beku (frozen product), baik dalam bentuk mentah (raw) atau masak (cooked) melalui proses pembekuan. produk kaleng (canned product) dilakukan proses pemanasan dengan menggunakan suhu tinggi (sterilisasi) serta pasteurisas, produk kering (dried product) melalui proses pengeringan alami atapun secara mekanis, produk asin kering (dried salted product) dilakukan proses penggaraman dan pengeringan alami ataupun mekanis, produk asap (smoked product) melalui proses pengasapan, produk fermentasi (fermented product) melalui proses fermentasi, p p produk masak (cooked product) melalui proses pemasakan/pengukusan, surimi based product, melalui proses leaching atau pengepresan (minched). Ikan merupakan salah satu komoditi yang menjadi sumber protein utama yang cukup penting bagi masyarakat Eropa. Saat ini, konsumsi ikan per kapita di Eropa sebesar $24.3 \mathrm{~kg}$. Namun, jumlah tersebut tidak merata, untuk di Eropa tengah dan timur, konsumsi ikan perkapita hanya sebesar $6 \mathrm{~kg}$, sekalipun tetap ada peningkatan konsumsi ikan perkapita, disamping peningkatan jumlah penduduk, 
terutama di Eropa barat dan utara. Saat ini konsumsi ikan perkapita di Portugal mencapai sekitar 30 $\mathrm{kg} / \mathrm{kapita}$. Di eropa saat ini terdapat masalah berupa penurunan produksi perikanan, hal ini terkait dengan kurang bisa bersaingnya harga produk dengan kualitas hasil produksi perikanan dan ikan tangkap dari Asia, sekalipun kualitas produknya sangat bagus. Selain itu, meskipun harga produk perikanan cukup tinggi di pasar setempat, industri perikanan di Eropa kurang memberikan income yang memadai bagi warga Eropa.

Untuk memenuhi kebutuhan ikan Eropa, saat ini Uni Eropa sendiri melakukan berbagai usaha peningkatan produksi, namun dengan tetap memperhitungkan faktor keberlanjutan dan proteksi terhadap populasi ikan. Hal ini sejalan dengan kebijakan dari FAO tahun 2015, dimana FAO menekankan pada pengimplementasian produksi perikanan berbasis science, manajemen budidaya perikanan yang baik, serta transparansi pemanfaatan dan perdagangan ikan secara internasional. Uni Eropa berkomitmen untuk produk perikanan harus dapat dipertanggung jawabkan yang dikonsumsi di Eropa (baik hasil budidaya sendiri maupun impor) memenuhi syarat keberlanjutan serta tidak merusak alam.

\section{Ekspor Hasil Perikanan Indonesia Menurut Komoditas}

Komoditas ekspor hasil perikanan yang utama pada tahun 2020 berdasarkan buku statistik ekspor perikanan (2021). Komoditas ekspor antara lain meliputi Udang, Tuna-Tongkol Cakalang, Rumput Laut, Cumi-Sotong-Gurita, dan Rajungan-Kepiting. Udang merupakan komoditas ekspor yang paling tinggi baik secara volume maupun nilai pada tahun 2020 dengan volume sebesar 239.282.011 kilogram, dan nilai sebesar USD 2.040.184.255. dan pada tahun 2021 berdasarkan KKP (2021) dari beberapa komoditas tersebut mengalami kenaikan volume menjadi 394.483.332 kilogram dan kenaikan nilai menjadi USD 2.041.794.387.Pada kurun waktu 5 tahun terakhir, Udang mengalami kenaikan volume ekspor rata-rata sebesar 8,70\%, Tuna-Tongkol-Cakalang naik sebesar 10,95\%, Rumput Laut naik sebesar 1,15\%, Cumi-Sotong-Gurita naik sebesar 4,21\%, Rajungan-Kepiting turun sebesar $1,08 \%$, dan komoditas lainnya naik sebesar 2,90\% per tahun. Secara total, volume ekspor hasil perikanan Indonesia pada periode 2016-2020 mengalami kenaikan rata-rata sebesar 4,13\% per tahun (statistik ekspor perikanan. 2021).

Sepuluh negara tujuan ekspor dengan volume hasil perikanan terbesar pada tahun 2020 yaitu Tiongkok, Amerika Serikat, Jepang, Thailand, Malaysia, Vietnam, Taiwan, Singapura, Korea Selatan, dan Arab Saudi. Sedangkan berdasarkan nilai ekspor hasil perikanan, sepuluh terbesar negara tujuan ekspor pada tahun 2020 yaitu Amerika Serikat, Tiongkok, Jepang, Thailand, Vietnam, Taiwan, Malaysia, Italia, Hongkong, dan Singapura. Tiongkok merupakan negara tujuan ekspor hasil perikanan dengan volume terbesar pada tahun 2020 sebesar 422.564 .850 kilogram, sedangkan Amerika Serikat merupakan negara tujuan ekspor hasil perikanan dengan nilai tertinggi pada tahun 2020 sebesar USD 2.096.627.031.

Tabel 2. Volume dan Nilai Ekspor Menurut Komoditas Utama Tahun 2016-2020

\begin{tabular}{|l|l|l|l|l|l|l|}
\hline Komoditas & 2016 & 2017 & 2018 & 2019 & 2020 & Trend (\%) \\
\hline Udang & 171.882 .960 & 180.592 .220 & 197.433 .608 & 207.704 .831 & 239.282 .011 & 8,70 \\
\hline Tuna-Tongkol-Cakalang & 138.396 .367 & 198.151 .578 & 168.433 .759 & 184.130 .234 & 195.759 .299 & 10,95 \\
\hline Rumput laut & 188.298 .633 & 191.853 .522 & 212.961 .523 & 209.241 .303 & 195.573 .600 & 1,15 \\
\hline Cumi-Sotong-Gurita & 122.134 .477 & 120.399 .288 & 152.108 .581 & 143.847 .343 & 140.036 .315 & 4,21 \\
\hline Rajungan-Kepiting & 29.040 .382 & 27.067 .093 & 27.791 .618 & 25.942 .911 & 27.616 .332 & $-1,08$ \\
\hline Lainnya & 425.410 .082 & 360.042 .847 & 367.339 .310 & 413.329 .067 & 464.580 .436 & 2,90 \\
\hline Volume (Kg) & $\mathbf{1 . 0 7 5 . 1 6 2 . 9 0 1}$ & $\mathbf{1 . 0 7 8 . 1 0 6 . 5 4 8}$ & $\mathbf{1 . 1 2 6 . 0 6 8 . 3 9 9}$ & $\mathbf{1 . 1 8 4 . 1 9 5 . 6 9 0}$ & $\mathbf{1 . 2 6 2 . 8 4 7 . 9 9 3}$ & $\mathbf{4 , 1 3}$ \\
\hline Nilai (USD) & $\mathbf{4 . 1 7 2 . 2 4 2 . 6 2 7}$ & $\mathbf{4 . 5 2 4 . 4 1 6 . 2 4 9}$ & $\mathbf{4 . 8 6 0 . 9 0 3 . 5 8 2}$ & $\mathbf{4 . 9 3 5 . 9 6 4 . 8 0 1}$ & $\mathbf{5 . 2 0 5 . 2 1 4 . 0 0 9}$ & $\mathbf{5 , 7 2}$ \\
\hline
\end{tabular}




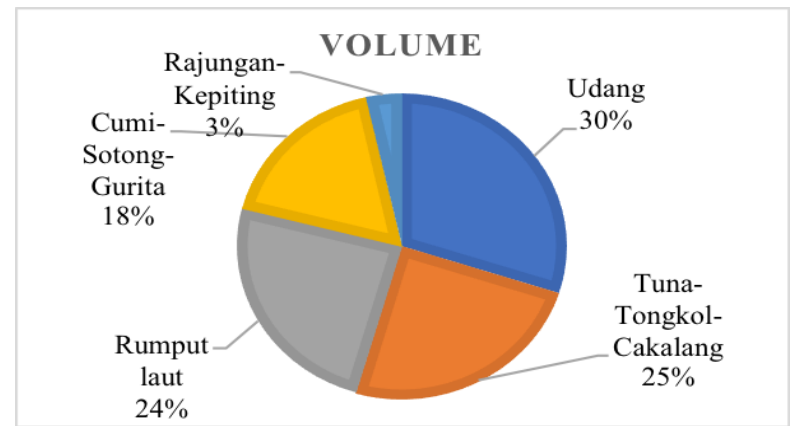

Gambar 1. Kontribusi Volume dan Nilai Ekspor Menurut Komoditas Utama Tahun 2020

\section{Permasalahan dan Potensi Pasar Perikanan Eropa}

Menurut EUMOFA (2017) potensi pasar perikanan Eropa untuk negara-negara Eropa timur, konsumsi ikan dapat dikatakan relatif rendah dibandingkan wilayah lain di Eropa, di wilayah ini, pasar ikan sangat bergantung pada suplai lokal dan harga ikan. Namun, adanya suplai ikan dari bagian lain di Eropa turut memberikan dampak menurunkan harga produk perikanan menjadi lebih terjangkau di daerah tersebut. Karakter yang hampir sama dapat ditemukan di kawasan Eropa Tengah. Untuk negara-negara Eropa Barat, konsumsi ikan di wilayah ini relatif tinggi dimana ditunjang oleh tradisi kuliner dari masa lalu serta ketersediaan ikan segar yang cukup mudah diperoleh disana. Selain hal tersebut, gaya hidup baru terutama bagi generasi muda yang saat ini tinggi akan kesadaran kesehatan dan trend gaya hidup, serta seperti kebiasaan makan sushi turut andil meningkatkan tren konsumsi ikan di wilayah ini. Namun demikian, akhir-akhir ini masyarakat lebih banyak membeli produk perikanan di supermarket dibandingkan pasar ikan (EUMOFA, 2017).

Untuk negara-negara Eropa utara, konsumsi ikan di wilayah ini sangat bergantung pada impor. Dibandingkan dengan rata-rata wilayah lain di Eropa, wilayah ini relatif cukup rendah angka konsumsi produk perikanannya. Hal ini karena warga di kawasan ini menganggap produk-produk perikanan adalah barang yang bernilai cukup mahal, selain itu mereka mulai menyadari pentingnya aspek keberlanjutan dalam produksi makanan. Sedangkan kawasan Eropa selatan masih sangat bervariasi, dari Portugal yang jauh di atas rata-rata Eropa dalam mengkonsumsi ikan, hingga Kroasia yang dapat dikatakan cukup rendah apabila dibandingkan rata-rata perkapita Eropa (EUMOFA, 2017).

\section{Strategi Peningkatan Produksi Ekspor Perikanan dan Kelautan}

Strategi merupakan tujuan panjang dari suatu perusahaan/lembaga, serta pendayagunaan dan alokasi sumberdaya yang penting untuk mencapai tujuan tersebut (Rangkuti 2014). Perumusan strategi yang ada dilakukan melalui pembentukan matriks SWOT, dimana komponen matriks ini meliputi kekuatan, kelemahan, peluang, dan ancaman yang telah diidentifikasi sebelumnya. Analisis SWOT akan membandingkan antara faktor eksternal yang berupa peluang (opportunities) dan ancaman (threats) dengan faktor internal yang meliputi kekuatan (strengths) dan kelemahan (weaknesses). Matriks SWOT dapat dirumuskan sebagai alternatif strategi yang dapat digunakan untuk peningkatan produksi ekspor perikanan dan kelautan ke Uni Eropa. 
Tabel 3. Hasil identifikasi strengths, weaknesses, opportunities, threats (SWOT) komoditas perikanan dan kelautan Indonesia.

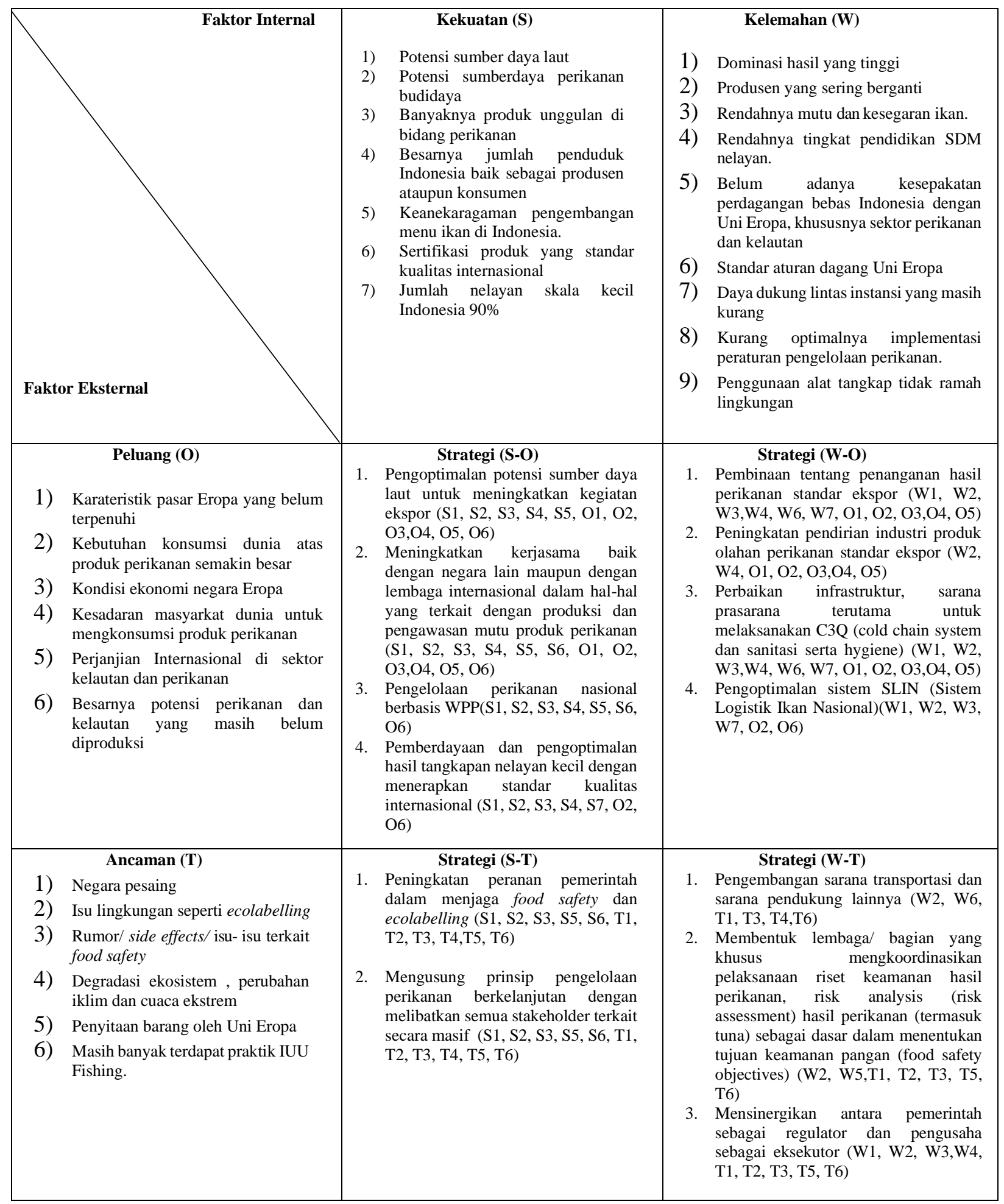


Volume 6 No 2 Februari 2022

P-ISSN : 2528-7044

E-ISSN : 2809-5103

DOI: https://doi.org/10.54964/manajemen/

\section{Strengths (Kekuatan)}

Mallawa (2006) menyatakan bahwa Indonesia menjadi habitat 44,7 persen ikan, 40 persen moluska, dan 8,6 persen rumput laut (Mallawa, 2006). Indonesia juga memiliki luas perairan mencapai 3,25 juta $\mathrm{km}^{2}$, luas perairan kepulauan mencapai 2,95 juta $\mathrm{km}^{2}$, laut teritorial seluas 0,30 juta $\mathrm{km}^{2}$, dan ZEE mencapai 2,55 juta $\mathrm{km}^{2}$ (Roza, 2017).

Berdasarkan data dari BPS, saat ini terdapat sekitar 12.857 desa yang berada di tepian laut, atau sekitar 18\% dari total desa di Indonesia yang berjumlah 71.074 (data per tahun 2018). Adapun untuk rumah tangga yang menggantung kan hidupnya dari budidaya perikanan, maka saat ini terdapat sekitar 1.5juta rumah tangga seluruh Indonesia pada sektor ini. Hampir setengahnya bergerak pada kegiatan budidaya kolam (892.249), diikuti terbanyak kedua dan ketiga adalah pada kegiatan tambak (263.530) serta sawah/mina-padi (178.495).

Berdasarkan buku statistik ekspor perikanan (2021). Tahun 2020, neraca perdagangan hasil perikanan Indonesia mencapai surplus USD 4,777 Miliar. Surplus ini merupakan yang tertinggi pada periode 2016-2020, sedangkan yang terendah pada tahun 2016 dengan surplus sebesar USD 3,789 Miliar. Neraca perdagangan Indonesia dalam kurun waktu 5 tahun, dari 2016-2020 naik sebesar 6,00\% per tahun. Ekspor hasil perikanan Indonesia pada tahun 2020 mencapai USD 5,205 Miliar. Nilai ekspor hasil perikanan juga menunjukkan tren positif dengan kenaikan sebesar $5,72 \%$ per tahun dalam periode 2016-2020. Impor hasil perikanan Indonesia pada tahun 2020 sebesar USD 428 Juta. Nilai impor mengalami kenaikan rata-rata sebesar 3,13\% pada periode yang sama. Berdasarkan KKP (2020) saat ini lebih dari 90\% nelayan Indonesia adalah nelayan kecil yang menangkap ikan di daerah pesisir. Hal tersebut menjadi peluang yang besar sekaligus tantangan untuk memperkuat usaha perikanan tangkap skala kecil agar lebih maju, mandiri, dan berkelanjutan.

\section{Weakness (Kelemahan)}

Produsen/pelaku industri perikanan sering berganti (sering ganti pelaku) tetapi menggunakan approval number yang sama. Hal ini sangat berisiko karena dari segi manajerial, kompetensi dalam pengendalian mutu keamanan hasil perikanan, dan pengalaman dalam pedagangan sebagai eksportir tentu tidak dapat dipertangungjawabkan. Disamping itu masih banyak pengusaha penangkapan yang belum memahami pentingnya menjaga mutu ikan sejak proses produksi sehingga mempengaruhi mutu produk yang dihasilkan perusahaan pengolaha. Masalah lain yang sering disampaikan oleh para ahli, salah satunya berdasarkan tim peneliti pada (RD Institut), mengungkap bahwa kelemahan sektor perikanan dan kelautan di Indonesia ialah adanya dominasi yang sangat tinggi dari nelayan tradisional skala kecil untuk melakukan kegiatan penangkapan ikan serta UMKM untuk budidaya. Nelayan tradisional ini dalam beroperasi menangkap ikan di lautan hanya menggunakan perahu serta peralatan tangkap tradisional, sehingga kemampuan jelajah dan tonase tangkapnya relatif sangat kecil. Data (RD Institut) juga memperlihatkan bahwa sebagian besar (99\%) nelayan Indonesia menggunakan kapal dengan ukuran < 30 GT serta fishing gears yang kurang efisien dalam melakuakan kegiatan operasi penangkapan ikan, sehingga produktivitas daya tangkap rendah. Hanya sekitar $1 \%$ nelayan di tanah air yang sudah menggunakan kapal di atas 30 GT. Kelemahan ini tentu membuka peluang masuknya perahu dan kapal dari luar Indonesia dengan kapasitas yang jauh lebih besar, mengingat selama ini nelayan Indonesia masih belum memanfaatkan potensi laut dengan perlengkapan yang mumpuni.

Selain hal tersebut rendahnya kualitas sumberdaya manusia (SDM) nelayan dan petugas pengawas Indonesia juga menjadi salah satu permasalahan dalam pengembangan sektor perikanan. Kualitas/kompetensi SDM nelayan dan pengawas di Indonesia masih perlu diperbaiki sementara pendidikan dan training amat sangat jarang diadakan (bisa disebut tidak ada program) dan tidak 
Volume 6 No 2 Februari 2022

P-ISSN : 2528-7044

E-ISSN : 2809-5103

DOI: https://doi.org/10.54964/manajemen/

direncanakan dengan komprehensif. Perusahaan ataupun nelayan perorangan biasanya akan mengirim karyawannya ataupun anggotanya hanya bila ada training yang diadakan oleh Pemerintah secara gratis.

Kelemahan berikutnya dari tata industri perikanan adalah terkait sisi kelembagaan perusahaan penangkapan ikan. (BPS, 2019) menyatakan bahwa hingga 2018, perusahaan penangkapan ikan yang sudah resmi terdaftar baru mencapai 127 perusahaan, yang mana terdiri dari PMA sebanyak 3 perusahaan, PMDN sebanyak 88 perusahaan dan jenis lainnya sebanyak 36 perusahaan. Kelemahan minimnya dari sisi registrasi serta kelembagaan perusahaan tangkap ini tentu menghasilkan banyak kendala, antara lain seperti : kesulitan akses terhadap perbankan untuk permodalan bagi pengusaha ataupun nelayan perorangan yang bergerak di sektor perikanan dan kelautan, termasuk optimalisasi fasilitas finansial dan perpajakan yang terus diupayakan oleh Pemerintah. Tingkat registrasi dan status kelembagaan yang masih rendah juga terjadi pada sektor budidaya. Sampai dengan tahun 2018, baru terdapat sebanyak 258 perusahaan budidaya perikanan yang secara resmi sudah terdaftar, yang terdiri dari 126 perusahaan budidaya tambak, 73 perusahaan pembenihan, 45 untuk budidaya laut, dan 14 untuk budidaya tawar (BPS, 2019). Kelemahan rendahnya status registrasi kelembagaan perusahaan di sektor budidaya memberikan efek merembet pada rendahnya kredit usaha pada lapangan usaha budidaya, termasuk menjadi halangan dalam penyaluran fasilitas dari berbagai lembaga yang menuntut status perusahaan yang akan menerima bantuan

Menurut Mariza (2016) Industri perikanan Indonesia juga masih didominasi oleh penjualan barang mentah, hal ini pun juga masih terhambat oleh kebijakan bea masuk yang belum terselesaikan dengan negara-negara pengimpor hasil laut Indonesia. Kelemahan terakhir yang terkait dengan sektor kelautan dan perikanan adalah sedikitnya jumlah fasilitas pelabuhan perikanan di Indonesia. Data dari Kementerian Kelautan dan Perikanan memperlihatkan bahwa sampai saat ini terdapat sebanyak 538 pelabuhan perikanan. Namun demikian, berbagai temuan ahli menyampaikan bahwa kondisi pelabuhan perikanan di Indonesia masih memerlukan sentuhan serius dari banyak pihak hal ini guna mendukung tata niaga perikanan sehingga produk perikanan dan kelautan di Indonesia dapat menjaga kualitas produknya serta dapat memenuhi standar pengiriman yang layak secara global khususnya ke Uni Eropa.

Permasalahan lainnya yakni nelayan Indonesia juga kekurangan infrastruktur pendukung selain pelabuhan. Misalnya berupa akses penyediaan kebutuhan listrik secara mencukupi untuk pemenuhan sistem rantai dingin, seperti cold storage, air blast freezer, contact plate, ice flake machine, dan lainlain. Padahal lokasi produksi biasanya berada di lokasi terpencil. Sedangkan infrastruktur tersebut kebanyakan berada di kota-kota besar yang bukan penghasil perikanan langsung. Pada tahun 2015, ketersediaan cold storage baru mencapai 200.000 ton/tahun, sedangkan kebutuhannya mencapai 1,32 juta ton/tahun, dan 1,7 juta ton/tahun di tahun 2017 mendatang. Sebagai perbandingan, di Jawa kebutuhannya mencapai 515.000 ton/tahun, namun baru tersedia sebanyak 118.000 ton/tahun. Demikian pula di wilayah Maluku dan Papua, dari kebutuhan mencapai 68.000 ton/tahun, baru tersedia sebanyak 14.000 ton/tahun (Mariza, 2016)

Koordinasi dan sinergi antar lembaga yang terkait dengan pembinaan dan pengawasan mutu hasil perikanan masih belum terpadu. Dari informasi yang diperoleh selama survey lapang diketahui bahwa antar lembaga terkait, terutama yang lintas sektoral sangat sulit untuk melakukan koordinasi.

Kelemahan selanjutnya yaitu masih kurang optimalnya penerapan implementasi peraturan pengelolaan perikanan sehingga menurunkan stok sumber daya ikan di alam dikarenakan nelayan kecil juga masih menggunakan alat tangkap tidak ramah lingkungan sehingga dalam kegiatan operasi penangkapan masih tidak terkontrol dengan baik dan dalam hal ini masih mengambil semua tanpa memikirkan keberlanjutan sumberdaya ikan kedepan. 


\section{Opportunity (Peluang)}

FAO 2018 menyatakan bahwa Indonesia konsisten sebagai negara dengan produksi hasil perikanan no 2 di dunia selama bertahun-tahun. Namun, perihal mengenai negara eksportir hasil perikanan, maka Indonesia hanya menempati peringkat ke 12 dunia pada tahun 2018, dan bahkan turun 3 peringkat ke peringkat 15 pada tahun 2019. Dari total produksi perikanan Indonesia, hanya sebanyak $4 \%$ yang diekspor ke negara lain. Padahal permintaan dunia akan ikan yang terus meningkat yang dipicu oleh pertambahan jumlah penduduk dunia dan timbulnya kesadaran akan pangan yang menyehatkan (red meat ke white meat, banyaknya kasus keamanan pangan pada produk daging dan unggas).

Salah satu peluang lainnya ialah adanya mutual recognition arrangement/agreement (kerjasama antar Negara). Kesediaan negara-negara importir untuk memberikan toleransi bagi pencapaian standar mutu yang ditetapkan bagi perusahaan pengolahan Indonesia. Toleransi standar mutu yang diberikan oleh negara importir lebih disebabkan oleh masih lebih tingginya permintaan dibandingkan dengan penawaran dari negara-negara produsen produk perikanan. Sehingga apabila produk perikanan dari negara pesaing sudah lebih baik mutunya dan penawaran sudah lebih banyak dari permintaan, maka tentunya toleransi ini akan dicabut.

Ikan merupakan salah satu komditi sumber protein utama yang cukup penting dan dibutuhkan bagi masyarakat di Eropa. Saat ini, konsumsi ikan per kapita di Eropa hanya $24.3 \mathrm{~kg}$. Dari sisi jenis spesies konsumsi ikan, penduduk di Eropa menyantap cukup tinggi ikan tuna yang sudah diproses dalam bentuk pengalengan (canned). Data (EUMOFA, 2017), pada tahun 2017 angka konsumsi ikan tuna per kapita di Eropa bahkan mencapai 3,07 kg per kapita per tahun. Angka ini bahkan lebih besar dari tiga jenis ikan lainnya yang diproduksi di Eropa, antara lain seperti ikan cod (2.31kg/kapita), ikan salmon $(2.24 \mathrm{~kg} / \mathrm{kapita})$, dan alaska pollock (1.59kg/kapita). Dalam hal untuk memenuhi kebutuhan ikan Eropa, Uni Eropa sendiri mengusahakan dengan berbagai usaha peningkatan produksi, namun dengan tetap memperhitungkan faktor keberlanjutan dan proteksi terhadap populasi ikan (KBRI Brussel. 2021)

\section{Threads (Ancaman)}

Ancaman yang terkait dengan perikanan dan kelautan di Indonesia diidentifikasi sebanyak tiga hal. Pertama, tingginya illegal fishing dan destructive fishing, khususnya oleh nelayan asing yang masih marak di perairan Indonesia. Kondisi tersebut dapat terjadi karena dua faktor antara lain; Faktor pertama dan yang paling utama ialah masih sedikitnya kapal ikan Indonesia di atas >30 GT yang beroperasi di fishing ground yang selama ini fishing ground tersebut dimanfaatkan dan dijarah nelayan asing. Adapun faktor kedua ialah lemahnya law enforcement dari aparat penegak hukum dan instansi terkait di Indonesia. Salah satu program kerja Kementerian Kelautan dan Perikanan yang sangat gencar adalah melakukan penangkapan dan penenggelaman kapal asing ilegal hingga pertengahan tahun 2019 perogram ini sebetulnya cukup efektif dan bagus dalam mengatasi ancaman ini. Namun demikian, upaya tersebut tentu harus terus dilanjutkan dan ditingkatkan penegakannya. Ancaman yang selanjutnya adalah status pemanfaatan potensi sumber daya ikan di perairan Indonesia yang kurang memperhatikan faktor dari keberlangsungan jangka panjang (sustainability) hayati dari ekosistem ikan atau komoditas tersebut.

Persaingan pedagangan perikanan internasional yang semakin ketat. Beberapa negara pesaing Indonesia lebih siap dalam menghadapi pemberlakuan standar mutu produk perikanan yang ditetapkan oleh negara importir produk perikanan. Filipina, Thailand, Vietnam, China serta beberapa negara pesaing dari Asia dan Amerika Selatan, telah sejak lama menerapkan standar mutu produk yang disesuaikan dengan standar yang ditetapkan oleh negara-negara pembeli. Penerapan standar mutu juga disertai dengan penyediaan fasilitas pendukung yang lengkap seperti ketersediaan alat 
pendingin atau es yang mencukupi di daerah-daerah sentra produksi perikanan, fasilitas dan sumberdaya manusia laboratorium yang lengkap, sarana transportasi dan komunikasi yang memadai. Pemerintah negara-negara tersebut juga sangat mendukung upaya peningkatan ekspor produk perikanan, sehingga apabila ada produknya yang terkena detention atau rejection, maka pemerintahnya segera melakukan lobi kepada pemerintah negara importer.

Karakteristik persyaratan teknis yang diberlakukan tiap negara importir berbeda. Penetapan standar mutu yang tidak sama diantara negara-negara importir produk perikanan Indonesia mengakibatkan perusahaan-perusahaan pengolahan harus terus berupaya untuk menyesuaikan standar mutu produknya sesuai dengan pasar masing-masing, diantaranya standar uji mikrobiologis, uji kimia dan uji fisik yang tidak sama, meskipun sebenarnya tujuannya sama yaitu untuk menjaga agar barang yang diimpor tersebut terjamin keamanannya untuk dikonsumsi oleh konsumen di setiap negara importir.

Adapun ancaman lain yang masih banyak ditemukan ialah masih terdapat dan maraknya praktik IUU Fishing di lapangan, dimana hal ini akan berdampak terhadap sektor ekspor produk kelautan dan perikanan dari Indonesia ke Uni Eropa, sebagai catatan dalam peraturan yang diterapkan oleh Uni Eropa salah satunya untuk produk ekspor dari bidang kelautan dan perikanan harus jelas dalam kegiatan penangkapan dan juga komitmen dalam menerapkan peraturan mencegah kegiatan IUU Fishing.

\section{Implikasi Strategi}

a) Strategi S-O

1. Pengoptimalan potensi sumber daya laut untuk meningkatkan kegiatan ekspor. Optimalisasi potensi perikanan yang ada untuk mendapatkan kualitas dan kuantitas yang maksimum sehingga dapat meningkatkan produksi untuk dapat memenuhi kebutuhan perikanan dalam negeri maupun untuk tujuan ekspor. Hal ini dapat dilakukan melalui perairan Indonesia yang potensial. Adapun hal yang dilakukan dengan memanfaatkan kekuatan yang ada, sebagai berikut : a. Pemanfaatan IPTEK secara optimal yang dapat mendukung dan meningkatkan produksi perikanan nasional; $b$. Merealisasikan potensi perluasan daerah penangkapan Indonesia sampai ke wilayah ZEE; c. Pemanfaatan Industri terkait dan pendukung yang dimiliki; d. Meningkatkan jumlah armada penangkapan diatas 30 GT agar bisa melakukan operasi penangkapan lebih optimal.

2. Meningkatkan kerjasama baik dengan negara lain maupun dengan lembaga internasional dalam hal-hal yang terkait dengan produksi dan pengawasan mutu produk perikanan.

3. Kerjasama baik dengan negara lain maupun dengan lembaga internasional perlu dilakukan dalam rangka harmonisasi standar mutu produk perikanan maupun dalam rangka kerjasana meningkatkan kualitas sumberdaya manusia dan kerjasama penelitian. Selama ini kerjasama yang dilakukan oleh pemerintah masih sangat terbatas akibatnya Indonesia sering mengalami kesulitan dalam mengikuti perkembangan standar mutu di pasar internasional. Implementasi strategi ini meliputi : i. Kerjasama penetapan pengawasan mutu (sertifikasi produk perikanan dan sistem mutu) dengan beberapa negara tujuan utama ekspor produk perikanan Indonesia. ii. Kerjasama dalam peningkatan kualitas sumberdaya manusia yang bekerja dalam bidang pengawasan mutu produk perikanan baik dengan lembaga internasional maupun dengan negara lain. iii. Kerjasama penelitian dalam rangka risk analysis produk pangan yang berasal dari hasil perikanan.

4. Pengelolaan perikanan nasional berbasis WPP

Sejauh ini ada lima provinsi yang memiliki hasil dan intensitas ekspor perikanan yang tinggi di Indonesia pada tahun 2020, antara lain yaitu: Provinsi Jawa Timur, DKI Jakarta, Sulawesi 
Selatan, Sumatera Utara, Jawa Barat. Dalam hal pengembangan ekspor perikanan di Indonesia seharusnya pemerintah tidak didasarkan dari daerah administratif, mengingat komoditas perikanan ini sangat dinamis, karena selalu berpindah dan bergerak. Untuk hal pengelolaan lebih baik pengembangannya berdasarkan Wilayah Pengelolaan Perikanan Republik Indonesia (WPP RI). Saat ini yang terjadi pengembangan yang didasarkan pada administrative. Dan hal ini hanya akan menimbulkan konflik dan tidak menggambarkan potensi sumber daya ikan sesungguhnya. Potensi sumber daya ikan memang lebih tepat untuk kegiatan yang mendorong pengembangan perikanan tangkap, sedangkan perikanan budi daya lebih dinamis.

5. Pemberdayaan dan pengoptimalan hasil tangkapan nelayan kecil dengan menerapkan standar kualitas internasional.

6. Indonesia memiliki nelayan yang sebagian besar merupakan nelayan yang tergolong nelayan skala kecil dimana jumlah nelayan skala kecil tersebut sekitar $90 \%$. Hal ini, dapat dijadikan salah satu strategi dalam menyokong peningkatan sektor ekspor dari bidang perikanan dan kelautan, dimana pengusaha besar sebagai eksportir dalam memenuhi kebutuhan pasar harus melakukan kerjasama dalam hal pemberdayaan dan pengoptimalan hasil tangkapan nelayan skala kecil sebgai penyokong bahan baku agar dapat lebih maksimal, namun tetap harus diterapkan standar kualitas hasil tangkapan yang mengacu berdasarkan syarat dan ketentuan dari Uni Eropa baik dalam hal ukuran, kebersihan, penanganan serta pengolahan hasil tangkapan.

\section{b) Strategi W-O}

1. Pembinaan tentang penanganan hasil perikanan standar ekspor

Dalam hal ini pemerintah selaku penyedia dan jembatan bagi para eksportir, seharusnya tidak hanya mengeluarkan regulasi, melainkan pemerintah membuat lembaga atau bagian khusus yang mana bertugas untuk membina para eksportir dalam hal ini perusahaan agar hasil perikanan yang dihasilkan/diolah dapat sesuai dengan standar yang diminta dan diterapkan di Uni Eropa.

2. Peningkatan pendirian industri produk olahan perikanan standar ekspor. Perbaikan infrastruktur, sarana prasarana terutama untuk melaksanakan C3Q (cold chain system dan sanitasi serta hygiene)

3. Mendorong implementasi rantai dingin (cool chain) dan sanitasi hygiene berupa meningkatkan volume ketersediaan es yang memenuhi syarat di sentra-sentra perikanan, pengembangan palka berinsulasi atau refrigerated sea water.

4. Pengoptimalan sistem SLIN (Sistem Logistik Ikan Nasional) Kementerian Kelautan dan Perikanan selaku pemegang wewenang terkait sector perikanan dan kelautan telah mempunyai sebuah sistem dimana sistem tersebut dinamakan Sistem Logistik Ikan Nasional (SLIN), SLIN merupakan suatu sistem yang pada intinya suatu jaringan pemasokan bahan baku terpadu yang dikembangkan secara nasional. SLIN merupakan sistem yang mengumpulkan ikan dari daerah-daerah produsen dan kemudian dikirim ke daerah konsumen (industri). Fungsi dari SLIN lainnya yaitu menyimpan dan mendistribusikan ikan ke daerah konsumen dan industri. SLIN saat ini sudah ditetapkan kedalam Peraturan Menteri Kelautan dan Perikanan No. 5 Tahun 2014.

Pada kenyataannya sistem logistik ikan nasional ini tidak mudah dijalankan dan memiliki beberapa masalah dan hambatan, salah satunya karena ikan bersifat perishable sehingga penanganan logistiknya lebih kompleks dan mahal, terutama dalam hal penyimpanan. Serta, perlu dirumuskan 
juga bagaimana model kelembagaannya, infrastruktur distribusi dan transportasi harus dikembangkan untuk menjamin konektivitas. Sistem logistik perikanan memiliki tujuan untuk meningkatkan daya saing produk perikanan Indonesia, khususnya produk perikanan olahan dan perikanan segar sebagai bahan baku perikanan olahan. Sistem ini dilakukan guna mendukung kebijakan industrialisasi perikanan. Oleh karena itu, kebijakan sistem logistik perikanan seyogyanya harus mengakomodasi kegiatan industri rumah tangga yang bergerak pada pengolahan hasil perikanan. Secara umum, sistem logistik perikanan nasional merupakan upaya dari pemerintah dalam mengelolaa komoditi perikanan agar produk perikanan dapat cepat sampai ke konsumen, dengan tetap menjaga kualitas produk perikanan yang dihasilkan. Sistem ini seharusnya bisa menjadi salah satu solusi permasalahan nelayan dan industri perikanan. Kebijakan sistem logistik perikanan tidak bisa dipisahkan dari upaya menjaga standar keamanan mutu hasil perikanan, agar hasil perikanan yang dihasilkan tetap segar, tidak tercemar residu hasil cemaran, dan bebas wabah penyakit ikan.

\section{c) Strategi S-T}

1. Peningkatan peranan pemerintah dalam menjaga food safety dan ecolabelling

Meningkatkan sense of quality pada perusahaan penangkapan, dan perusahaan pengolahan mengenai pentingnya menjaga mutu ikan mulai dari proses produksi hingga proses pengolahan. Mengupayakan adanya penyuluhan mengenai pentingnya menjaga mutu ikan mulai dari proses produksi hingga proses pengolahan. Hal ini disebabkan masih tetap rendahnya kesadaran pelaku usaha perikanan, khususnya pengusaha penangkapan atau nelayan dan pembudidaya, untuk menerapkan rantai dingin (cool chain) selama proses pengangkutan ikan sejak ikan ditangkap atau ikan dipanen hingga sampai perusahaan pengolahan atau sampai ke tangan konsumen.

2. Mengusung prinsip pengelolaan perikanan berkelanjutan dengan melibatkan semua stakeholder terkait secara masif. Dalam kegiatan penangkapan dan pembudidayaan ikan saat ini sudah harus menerapkan prinsip pengelolaan perikanan secara berkelanjutan. Hal ini berkaitan dengan mulai banyak gerakkan masyakat internasional yang memiliki kesadaran dan kepedulian bahwa pemanfaatan sumber daya ikan harus memerhatikan keberlanjutan dan untuk keberadaan generasi mendatang. Karena, pemanfaatan sumber daya ikan sangat berkaitan erat dengan aspek kelestarian lingkungan. Saat ini, masih banyak pemanfaatan sumber daya ikan yang menggunakan bahan peledak dan penggunaan pakan berbahaya. Hal ini akan berdampak sangat negatif bagi kesehatan manusia sudah tidak bisa lagi dibenarkan. Dalam kegiatan pemanfaatan sumber daya ikan juga harus mulai dipikirkan dengan cara berkelanjutan. dan tidak dilakukan dengan cara bertentangan hukum internasional sehingga aspek pelacakan (traceability) telah menjadi syarat dari importir atau negara tujuan ekspor bisa terpenuhi.

3. Traceability/Pelacakan didefinisikan oleh Codex Alimentarius sebagai "kemampuan mengikuti pergerakan makanan melalui tahap produksi, pengolahan, dan distribusi". Dimana traceability selain berperan dalam menyediakan informasi terkait dengan persyaratan keamanan pangan, penelusuran atau pelacakan dari produk perikanan juga penting bagi pengembangan alat yang efektif untuk memberantas IUU fishing. Peraturan di Uni Eropa No 1005 tahun 2008 sudah mengatur perihal tersebut. Berdasarkan peraturan tersebut, setiap perdagangan seafood di Uni Eropa harus dilakukan oleh kapal penangkapan ikan yang memiliki sertifikat penangkapan yang dikeluarkan oleh otoritas yang bertanggung jawab terhadap pengelolaan perikanan. Saat ini Jepang, termasuk juga ikut menandatangani kesepakatan bekerja sama dengan Uni Eropa dalam memerangi IUU fishing melalui larangan impor seafood yang ditangkap secara tidak sah.

\section{d) Strategi W-T}

1. Pengembangan sarana transportasi dan sarana pendukung lainnya. 
2. Membentuk lembaga/bagian yang khusus mengkoordinasikan pelaksanaan riset keamanan hasil perikanan, risk analysis (risk assessment) hasil perikanan (termasuk tuna) sebagai dasar dalam menentukan tujuan keamanan pangan (food safety objectives).

3. Mensinergikan antara pemerintah dan pengusaha

Kerugian yang terjadi terhadap pengusaha juga akan berdampak kepada pemerintah. Hal tersebut dikarenakan apabila sudah terjadi pelanggaran yang bersifat kumulatif dari suatu negara, maka negara anggota Uni Eropa akan melakukan penolakan terhadap perdagangan hasil tangkapan ikan dari pihak negara pengekspor. Sehingga perlu adanya kerjasama antara pemerintah dan pengusaha. Solusi dari hal tersebut adalah dengan menyinergiskan antara pemerintah dan pengusaha. Hal tersebut dapat dilakukan dengan cara sosialisasi secara berkala kepada pihak pengusaha. Pembahasan yang dapat dilakukan berupa permasalahan notifikasi yang terjadi, strategi yang dilakukan untuk meminimalisir notifikasi dan starategi teknis terkait ekspor menuju Uni Eropa.

\section{PENUTUP}

Berdasarkan hasil analisis yang telah dilakukan maka dapat diambil beberapa kesimpulan yaitu:

1. Komoditas ekspor industri perikanan Indonesia dengan kode HS 0303 memiliki keunggulam komparatif. Hal ini ditunjukan melalui statistik perikanan dari tahun 2016-2020 dengan jumlah volume ekspor yang paling tinggi dan nilai paling besar.

2. Dari analisis SWOT di dapat berbagai implikasi strategi dan lebih mengarah kepada strategi untuk: Pengoptimalan potensi sumber daya laut untuk meningkatkan kegiatan ekspor; Meningkatkan kerjasama baik dengan negara lain maupun dengan lembaga internasional dalam hal-hal yang terkait dengan produksi dan pengawasan mutu produk perikanan; Pengelolaan perikanan nasional berbasis WPP; Pemberdayaan dan pengoptimalan hasil tangkapan nelayan kecil dengan menerapkan standar kualitas internasional; Peningkatan peranan pemerintah dalam menjaga food safety dan ecolabelling; Mengusung prinsip pengelolaan perikanan berkelanjutan; Pengembangan sarana transportasi dan sarana pendukung lainnya; Membentuk lembaga/bagian yang khusus mengkoordinasikan pelaksanaan riset keamanan hasil perikanan, risk analysis (risk assessment) hasil perikanan (termasuk tuna) sebagai dasar dalam menentukan tujuan keamanan pangan (food safety objectives); Mensinergikan antara pemerintah sebagai regulator dan pengusaha sebagai eksekutor.

3. Selain strategi tersebut dibutuhkan beberapa strategi pendukung lainnya seperti : sinergitas otoritas perpajakan, bea cukai dan Lembaga pembiayaan sektor perikanan dan kelautan; sinergitas pengembangan kawasan industri terpadu; peningkatan armada kapal diatas $30 \mathrm{GT}$ berbasis badan usaha milik desa/koperasi; Optimalisasi Sumber Pembiayaan Alternatif untuk Inisiatif Konservasi Sustainabilitas Perikanan dan Kelautan.

\section{DAFTAR PUSTAKA}

[KEDUBES RI] Kedutaan Besar Republik Indonesia-Bratislava. 2015. Peluang Ekspor Produk Fresh Fish, Seafood, Dan Ikan Olahan Indonesia Ke Slovakia. https://kemlu.go.id/download/L1NoYXJ1ZCUyMERvY3VtZW50cy9NYXJrZXQ INYXJrZXQIMjBJ2VuY2UlMjBQcm9kdWslMjBLZWxhdXRhbi5wZGY=.Kem enterian Luar Negeri Republik Indonesia. Diunduh pada 13 November 2021.

[KEDUBES RI] Kedutaan Besar Republik Indonesia-Brussel. 2021. Merespon Potensi Ekonomi Pasar Produk Perikanan Eropa Dan Tuntutan Perlindungan Lingkungan: Kajian 
Strategi Peningkatan Kapasitas Sektor Perikanan Dan Kelautan Indonesia Yang Berkelanjutan. [Research Series]. Edisi 2021, No.2.

[KEMENDAG] Kementerian Perdagangan. 2021. Satudata perkembangan ekspor nonmigas (Komoditi).https://satudata.kemendag.go.id/growth-of-non-oil-and-gas-exportcommodity.

[KKP] Kementerian Kelautan dan Perikanan. 2021. Buku Statistik Ekspor Perikanan dan Kelautan 2016-2020. Dirjen Penguatan Daya Saing Produk kelautan dan perikanan. Jakarta. 929 hal.

[KKP] Kementerian Kelautan dan Perikanan. 2020. "Siaran pers KKP, September 2020. https://kkp.go.id/artikel/23309-berdayakan-perikanan-skala-kecil-kkpdorong-perekonomian-nasional-dan-asean. Diakses tanggal 9 Desember 2021

[KKP] Kementerian Kelautan dan Perikanan. 2019. "Kinerja Pembangunan Kelautan dan Perikanan s/d Agustus 2019", Jakarta

Baransano, H.K., \& Mangimbulude, J.C. (2011). Eksploitasi dan Konservasi Sumberdaya Hayati Laut dan Pesisir di Indonesia. Jurnal Biologi Papua, 3 (1), 39-45.

Effendi, I., Yanfika, H., Sumaryo, S., Listiana, I., Mutolib, A., \& Rahmat, A. (2019). Has Empowerment Program Been Appropriate for the Need of Fisheries Business Player?: Case Study in Lampung Province, Indonesia. International Journal of Multicultural and Multireligious Understanding, 6(4), 317. https://doi.org/10.18415/ijmmu.v6i4.982

Eirikur, B, 2017, "Iceland: Ever-Lasting Independence Struggle". Nordic Nationalism and RightWing Populist Politics. Palgrave Macmillan UK. pp. 93-124

EUMOFA, 2017, "Cooked Shrimps in France : Prioce Structure in the Supply chain”, Brussels

EUMOFA, 2017, "Final Report : EU Consumer HabitsRegarding Fisheries and Aquaculture Product", ISBN: 978-92-79-69463-9 DOI: 10.2771/758623

Fahrudin A. 2003. Pengembangan Eskpor Produk Kelautan Indonesia Ke Eropa. Buletin Ekonomi Perikanan Volume V No 1.

FAO. 2020. The State of World Fisheries and Aquaculture 2020. Sustainability in action. Rome. https://doi.org/10.4060/ca9229en

FAO. 2020. The State of World Fisheries and Aquaculture 2020. Sustainability in action. Rome. https://doi.org/10.4060/ca9229en http://www.fao.org/3/cb1213t/CB1213T.pdf halaman 9 appendix 1 https://ec.europa.eu/fisheries/cfp/ https://hisconsulting.co.id/id/ekspor-perikanan-indonesia-baru-4-persen-dari-totalproduksi https://www.statista.com/statistics/1083946/indonesia-fisheries-contribution-togdp/\#: :text=In\%202018\%2C\%20fisheries\%20and\%20\%the,largest\%20fish\%20p roducer\%20after\%20China

Kusdiantoro., Fahrudin, A., Wisudo, S.H., \& Juanda, B. (2019). Kinerja Pembangunan Perikanan Tangkap di Indonesia. Buletin Ilmiah "MARINA" Sosial Ekonomi Kelautan dan Perikanan, 5 (2): 69-84.

Lahsen Ababouch, Stefania Vannuccini, and Victorio Chomo, (2016), Fisheries, Aquaculture Utilization and Trade: Challenges and Opportunities, in Trade and Environment Review 2016: Fish Trade, United Nations Conference on Trade and Development (UNCTAD). Lasabuda, R. (2013). Regional Development in Coastal and Ocean in Archipelago Perspective of The Republic of Indonesia. Jurnal Ilmiah Platax, 1 (2), 91-101. 
Lestari W., Syarief, R., \& Sumantadinata, K. (2013). Strategi Peningkatan Daya Saing Tuna Olahan Indonesia di Pasar Internasional. Manajemen IKM, 8(1): 36-44.

Mallawa, A. (2006). Pengelolaan Sumberdaya Ikan Berkelanjutan dan Berbasis Masyarakat. Lokakarya Agenda Penelitian Program COREMAP II, Kabupaten Selayar, 9 - 10 September 2006.

Mariza, N. 2016, "Kebijakan Percepatan Pembangun Industri Perikanan Nasional”, Transformasi, TR-2016/02

Nurlina. (2018). Analisis Keterkaitan Sub Sektor Perikanan Dengan Sektor Lain Pada Perekonomian Di Provinsi Aceh. Jurnal Samudra Ekonomika, 29( 1), 20-29.

Purnomo. (2015). Permasalahan Makro di Sektor Perikanan dan Alternatif Kebijakannya dalam buku Potret dan Strategi Pengembangan Perikanan Tuna, Udang, dan Rumput Laut Indonesia. Departemen Kelautan dan Perikanan, Jakarta.

Pursetyo, K.T., Tjahjaningsih, W., \& Pramono, H. (2015). Perbandingan Morfologi Kerang Darah di Perairan Kenjeran dan Perairan Sedati. Jurnal Ilmiah Perikanan dan Kelautan, 7(1), 3133

Putri, D.A.S., Rosjadi, F., \& Sundari, M.S. (2018). Daya Saing Ekspor dan Perkembangan Pangsa Pasar Ikan Tuna Indonesia di Pasar Internasional Periode 2012-2016. Ekonomi dan Bisnis, 23 (1), 1-18.

Rangkuti, F. 2003. Analisis SWOT Teknik Membedah Kasus Bisnis. PT Gramedia Pustaka Utama: Jakarta

Rangkuti, Freddy. 2014. Analisis SWOT: Teknik Membedah Kasus Bisnis. Jakarta: PT. Gramedia Pustaka Utama.

Rokhmin Dahuri Institute; https://bit.ly/3ocBP1i

Roza, E. (2017). Maritim Indonesia, Kemewahan Yang Luar Biasa. Jakarta: Kementerian Kelautan dan Perikanan Republik Indonesia. Downloaded from: https://kkp.go.id/artikel/2233- maritim-indonesia-kemewahan-yang-luar-biasa. [Diakses Tanggal: 18 November 2021]

Soemaryani, I., Tisnawati, E., \& Firmansyah, D. (2015). Pengembangan Model Kontribusi Network Governance dalam Value Chain untuk Meningkatkan Keunggulan Bersaing Usaha Perikanan Tangkap (Survei Pada Nelayan Perikanan Tangkap Di Kabupaten Indramayu). Jurnal Bisnis \& Manajemen, 16 (1), 38-46.

Subakir, A. A., Hubeis, M., Trilaksani, W. 2020. Strategi Peningkatan Konsumsi Ikan pada Masyarakat Berpendapatan Rendah Di Provinsi Jawa Tengah. Jurnal Manajemen IKM, Vol. 15 (1) 2020: 70-76. e-ISSN 2622-9250.

Tyas, A.A.W.P., \& Ikhsani, K.T.W. (2015). Sumber Daya Alam dan Sumber Daya Manusia Untuk Pembangunan Ekonomi Indonesia. Forum Ilmiah, 12 (1), 1-15. \#

Varadi. 2000, "Aquaculture Development Trend in Europe”, Fish Culture Research Institute, Szarvas Yanfika H, Amanah S, Fatchiya A, Asngari PS, Mutolib A, Rangga KK. 2020. Influence of extension activities on the competencies of traditional fisheries processing in Lampung Province. Jurnal Pengolahan Hasil Perikanan Indonesia, 23(1): 22-30

Yohan, N. (2006). Peningkatan Daya Saing Indonesia di Dalam Perdagangan Internasional. Universitas Borobudur, Jakarta.

Yusuf R, Muhartono R. 2017 Strategi Pengembangan Usaha Perikanan Tangkap Di kabupaten Kayong Utara. Jurnal kebijakan Sosial Ekonomi kelautan dan Perikanan. $12 \mathrm{hal}$.

Yusuf, R., Arthatiani, F.Y., \& Putri, H.M. (2017). Peluang Pasar Ekspor Tuna Indonesia : Suatu Pendekatan Analisis Bayesian. J. Kebijakan Sosek KP, 7(1), 39-50. 